\title{
Enterohemorrhagic Escherichia coli 0157:H7 from healthy dairy cattle in Mid-West Brazil: occurrence and molecular characterization $^{1}$
}

\author{
Edismauro G. Freitas Filho ${ }^{2}$, Marcos R.A. Ferreira ${ }^{3}$, Jefferson F.N. Pinto ${ }^{4}$, Fabrício R. \\ Conceição ${ }^{5}$ and Cecília N. Moreira ${ }^{3 *}$
}

\begin{abstract}
Freitas Filho E.G., Ferreira M.R.A., Pinto J.F.N., Conceição F.R. \& Moreira C.N. 2014. Enterohemorrhagic Escherichia coli 0157:H7 from healthy dairy cattle in MidWest Brazil: occurrence and molecular characterization. Pesquisa Veterinária Brasileira 34(1):24-28. Departamento de Medicina Veterinária, Centro de Ciências Agrárias e Biológicas, Universidade Federal de Goiás, Rodovia BR-364 Km 192 n 3.800, Pq. Industrial, Jataí, G0 75801-615, Brazil. E-mail: cissanm@yahoo.com.br

Enterohemorrhagic Escherichia coli (EHEC) serotype 0157:H7 represents the major Shiga toxin-producing E. coli (STEC) strain related to large outbreaks and severe diseases such as hemorrhagic colitis (HC) and the potentially lethal hemolytic uremic syndrome (HUS). The aim of this study was to report the occurrence and molecular characterization of 0157:H7 isolates obtained by rectal swab from 52 healthy dairy cattle belonging to 21 farms in Mid-West of Brazil. Detection of 16SrRNA, stx1, stx2, rfb0157, fliCh7, eae, ehxA, saa, cnf1, chuA, yjaA and TSPE4.C2 genes was performed by PCR. The isolates were further characterized by serotyping. Two hundred and sixty E. coli isolates were obtained, of which 126 were characterized as STEC. Two isolates from the same cow were identified as serotype 0157:H7. Both isolates presented the $s t \times 2$, eae, ehxA, saa and $\operatorname{cnf1} 1$ virulence factor genes and the chuA gene in the phylogenetic classification (virulent group D), suggesting that they were clones. The prevalence of $0157: \mathrm{H} 7$ was found to be $1.92 \%(1 / 52$ animals), demonstrating that healthy dairy cattle from farms in the Mid-West of Brazil are an important reservoir for highly pathogenic E. coli 0157:H7.
\end{abstract}

INDEX TERMS: Shiga toxin-producing Escherichia coli, STEC, hemorrhagic colitis, hemolytic uremic syndrome, reservoir, virulence factors.

RESUMO-- [Escherichia coli enterohemorrágica 0157: H7 em bovinos leiteiros saudáveis no Centro-Oeste do Brasil: ocorrência e caracterização molecular.] Escherichia coli enterohemorrágica (EHEC) sorotipo 0157:H7 re-

\footnotetext{
${ }^{1}$ Received on August 2, 2013.

Accepted for publication on October 26, 2013.

${ }^{2}$ Departamento de Biologia Celular e Molecular e Bioagentes Patogênicos, Faculdade de Medicina de Ribeirão Preto, Universidade de São Paulo (USP), Ribeirão Preto, SP 14049-900, Brazil.

${ }^{3}$ Departamento de Medicina Veterinária, Campus Jataí, Universidade Federal de Goiás (UFG), Rodov. BR-364 Km 192 no 3.800, Parque Industrial, Cx. Postal 3, Jataí, GO 75801-615, Brazil. *Corresponding author: cissanm@yahoo.com.br

${ }^{4}$ Departamento de Ciências Biológicas, Campus Jataí, UFG, Cx. Postal 3, Jataí, GO 75801-615, Brazil.

${ }^{5}$ Núcleo de Biotecnologia, Centro de Desenvolvimento Tecnológico, Universidade Federal de Pelotas (UFPel), Cx. Postal 354, Pelotas, RS 96010900, Brazil.
}

presenta as principais cepas de E. coli produtoras de toxina Shiga (STEC) relatadas em grandes surtos e doenças graves, tais como colite hemorrágica $(\mathrm{CH})$ e síndrome hemolítica urêmica (SHU), potencialmente letais. 0 objetivo deste estudo foi reportar a ocorrência e caracterização molecular de STEC 0157:H7 isoladas por swab retal de 52 bovinos saudáveis pertencentes a 21 rebanhos leiteiros do Centro-Oeste do Brasil. A detecção dos genes 16SrRNA, stx1, stx2, rfb0157, fliCh7, eae, ehxA, saa, cnf1, chuA, yjaA e TSPE4.C2 foi realizada por PCR. Os isolados foram ainda caracterizados por sorotipagem. Dos 260 isolados de E. coli obtidos, 126 foram caracterizados como STEC. Dois deles, oriundos do mesmo animal, foram caracterizados como pertencentes ao sorotipo 0157:H7. Ambos apresentaram os genes de virulência stx2, eae, ehxA, saa e cnf1 e na caracterização filogenética, o gene chuA (grupo patogênico D), sugerindo que eles foram clones. A prevalência de 0157:H7 foi de 
$1,92 \%$ (1/52 animais), demonstrando que os bovinos leiteiros saudáveis de fazendas do Centro-Oeste do Brasil são importantes reservatórios de E. coli 0157:H7 altamente patogênicas.

TERMOS DE INDEXAÇÃO: Escherichia coli produtoras de toxina Shiga, STEC, colite hemorrágica, síndrome hemolítica urêmica, reservatório, fatores de virulência.

\section{INTRODUCTION}

Brazil exports milk to several countries, and Goiás State (GO, Mid-West of Brazil) is the fourth largest producer, being responsible for $10.9 \%$ of the total production of 32.1 billion liters a year. Jataí city in GO is the third larger producer nationally (IBGE 2012). The milk yield in the Brazilian Midwest increased yearly by $5.13 \%$ from 1990 to 2010, contributing to a national increase of 3.66\% (Sousa et al. 2012). Currently, the control standards of Brazilian milk quality have become more stringent in order to avoid health problems for the consumer.

Enterohemorrhagic Escherichia coli (EHEC) strains are subsets of Shiga toxin (Stx)-producing E. coli (STEC) that are responsible for severe disease in humans. About 200 STEC serotypes have been isolated from animal and food sources, although not all are implicated in illness. However, serotype 0157:H7 is the major STEC strain related to large outbreaks and severe diseases such as hemorrhagic colitis (HC) and the potentially lethal hemolytic uremic syndrome (HUS) (Paton \& Paton 2002, Pennington 2010, Karmali et al. 2010). However, death has not been associated with many disease outbreaks in South American countries (Rúgeles et al. 2010, Tanaro et al. 2010, Rivero et al. 2011).

Human diseases caused by STEC involve at least one of the Shiga toxins (stx1 and stx2) that function as an N-glycosidase, cleaving a specific adenine from the $28 \mathrm{~S}$ rRNA, thereby halting protein synthesis (Johnson \& Nolan 2009). Other virulence factors involved are: intimin, an adhesin associated with a microscopic lesion, the attaching and effacing lesion, in intestinal epithelial cells, it is characterized by the destruction of host cell microvilli and intimate attachment of the bacteria to cup-like pedestals at the apical cell membrane from the host intestinal mucosa (Wang et al. 2002); Enterohemolysin, a pore-forming RTX toxin cytolysin, which is active on sheep erythrocytes and certain bovine lymphoma cell lines, and only rarely makes adherence possible for eae negative strains providing an example of a particularly virulent serotype (Cookson et al. 2007); STEC agglutinating adhesion (Saa), an adherence factor that is more important for attachment in the gut of animals than in humans (Bolton et al. 2011); and CNF-1 (cytotoxic necrotizing factor), which behaves as a virulence factor in urinary or digestive tract infections by stimulating PMNL cytotoxicity as a result of enhanced adherence to epithelial cells as well as the production of radical oxygen products (Blanco et al. 1996).

STEC strains are part of the intestinal microbiota of cattle, making them the primary reservoir for E. coli 0157:H7. Transmission to humans occurs through consumption of undercooked ground (minced) beef, unpasteurized milk, dairy products and vegetables or water contaminated with cattle feces (Cergole-Novella et al. 2006, Sandrini et al. 2007, Pennington 2010).

The aim of this study was to report the occurrence and molecular characterization of 0157:H7 isolates obtained by rectal swab from 52 healthy dairy cattle belonging to 21 farms in Mid-West of Brazil.

\section{MATERIALS AND METHODS}

Over a period of 10 months, from February to December 2012, a rectal swab was collected from each of 52 dairy non-diarrheic animals. Each swab was used to inoculate Stuart medium tubes (Difco Laboratories, Detroit, MI, USA), stored in an ice-pack container and analyzed within 24 hours. The farms were localized in different cities of the South West State. The samples were taken from 31 calves (less than 11 months old) and 21 cows (more than 24 months old). The fecal samples were streaked onto Levine BEM agar (Difco, Detroit, MI, USA) and incubated at $37^{\circ} \mathrm{C}$ for $24 \mathrm{~h}$. At least five individual suspect Escherichia coli colonies each animal (dark with a greenish metallic sheen) were chosen and their identity was confirmed by biochemical tests, including the utilization of citrate and the production of indole, acetoin and methyl red reactive compounds (Feng et al. 2009).

DNA samples were extracted from the isolates $(n=260)$ according to Keskimaki et al. (2001). Initially, these samples were analyzed by PCR for the presence of 16SrRNA (internal control), stx 1 and stx2, for STEC characterization. All isolates obtained were characterized by serotyping (tube agglutination test) at the Enterobacteria Laboratory at the Oswaldo Cruz Institute (Fiocruz, Rio de Janeiro, Brazil). DNA samples from 126 STEC positive isolates were analyzed by PCR for the presence of the $r f b 0157$ and fliCh7 genes, for identification of 0157:H7 isolates. DNA from the 0157:H7 positive isolates was analyzed by PCR for the presence of the eae, ehxA, saa and $c n f 1$ virulence factor genes. The primers used in this study are shown in Supplementary Table S1. The amplification protocol was carried out in a MJ Research thermocycler using the PCR test conditions as described previously: stx2 and rfb0157 (Paton \& Paton 1998), fliCh7 (Gannon et al. 1997), stx1 and eae (Wang et al. 2002), saa (Paton \& Paton 2002), ehxA (Blanco et al. 2004) and cnf1 (Yamamoto et al. 1995). E. coli 0157:H7 and Klebsiella pneumoniae DNA were used as positive and negative controls, respectively. These control strains, belonging to a collection maintained in the Technology Development Center/ Biotechnology of the Federal University of Pelotas, were characterized by genotypic and phenotypic methods.

Phylogenetic classification of E. coli 0157:H7 was performed by PCR following Clermont et al. (2000) using the chuA, yjaA and TSPE4.C2 genes (Supplementary Table 1). The 232/96 strain, kindly provided by the Laboratory of Bacteriology at the Federal University of Santa Maria, was used as a positive control.

\section{RESULTS}

Of the 260 colonies from the rectal swabs collected from 52 healthy animals from 21 farms, 126 were STEC positive. Of the STEC positive isolates, two were identified as 0157:H7 by PCR and serotyping, and both isolates originated from the same cow, suggesting that they were clones. These isolates were PCR positive for the $16 \operatorname{SrRNA}$ and stx 2 virulence factor genes (Fig.1a). Phylogenetic classification of the isolates characterized the $c h u A$ gene as belonging to virulent group D (Fig.1b). In addition, the virulence factor genes fli$\mathrm{Ch} 7, \mathrm{rbO} 157$ and eae were detected these isolates (Fig.1c). 
Table 1. Primer pairs used in the PCR for identification of the genes encoding virulence factors and phylogenetic classification

\begin{tabular}{|c|c|c|c|c|}
\hline Target gene & Primer Sequence & Amplicon (bp) & Location within gene & GenBank accessior \\
\hline \multirow[t]{2}{*}{ 16SrRNA } & CCCCCTGGACGAAGACTGAC & 401 & $1682-1701$ & AB035924 \\
\hline & ACCGCTGGCAACAAAGGATA & & $2063-2082$ & \\
\hline \multirow[t]{2}{*}{ stx1 } & TCTCAGTGGGCGTTCTTATG & 338 & $777-796$ & M17358 \\
\hline & TAСССССТСААСТGСТАAТА & & $1095-1114$ & \\
\hline \multirow[t]{2}{*}{ stx2 } & GGCACTGTCTGAAACTGCTCC & 255 & $603-623$ & NC_004914 \\
\hline & TCGCCAGTTATCTGACATTCTG & & $837-857$ & \\
\hline \multirow[t]{2}{*}{ eae } & ATGCTTAGTGCTGGTTTAGG & 248 & $132-151$ & Z11541.1 \\
\hline & GCCTTCATCATTTCGCTTTC & & $360-379$ & \\
\hline \multirow[t]{2}{*}{ saa } & CGTGATGAACAGGCTATTGC & 119 & $1423-1442$ & NC_007365.1 \\
\hline & ATGGACATGCCTGTGGCAAC & & $1522-1541$ & \\
\hline \multirow[t]{2}{*}{ ehxA } & GGTGCAGCAGAAAAAGTTGTAG & 1.551 & $238-259$ & ES204929.1 \\
\hline & TCTCGCCTGATAGTGTTTGGTA & & $1767-1788$ & \\
\hline \multirow[t]{2}{*}{ rfb0157 } & CGGACATCCATGTGATATGG & 259 & $393-412$ & JF713072.1 \\
\hline & TTGCCTATGTACAGCTAATCC & & $631-651$ & \\
\hline \multirow{2}{*}{ cnf1 } & AAGATGGAGTTTCCTATGCAGCAG & 498 & 794-817 & NC_00796.1 \\
\hline & CATTCAGAGTCCTGCCCTCATTATT & & $1267-1291$ & \\
\hline \multirow[t]{2}{*}{ chuA } & GACGAACCAACGGTCAGGAT & 279 & $245-264$ & AF280396.1 \\
\hline & TGCCGCCAGTACCAAAGACA & & $504-523$ & \\
\hline \multirow[t]{2}{*}{ yjaA } & TGAAGTGTCAGGAGACGCTG & 211 & $66-84$ & NC_007779.1 \\
\hline & ATGGAGAATGCGTTCCTCAAC & & $257-276$ & \\
\hline \multirow[t]{2}{*}{ TSPE4.C2 } & GAGTAATGTCGGGGCATTCA & 152 & $421-440$ & AE014075.1 \\
\hline & CGCGCCAACAAAGTATTACG & & $553-572$ & \\
\hline \multirow[t]{2}{*}{ fliCh7 } & GCGCTGTCGAGTTCTATCGAGC & 625 & 69-91 & AB781292.1 \\
\hline & CAACGGTGACTTTATCGCCATTCC & & $671-694$ & \\
\hline
\end{tabular}

(A)

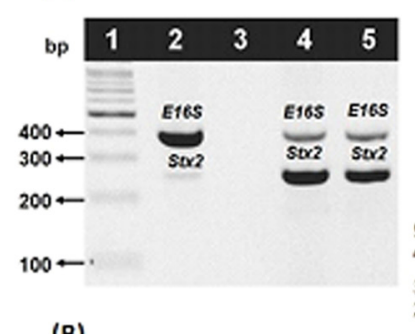

(c)

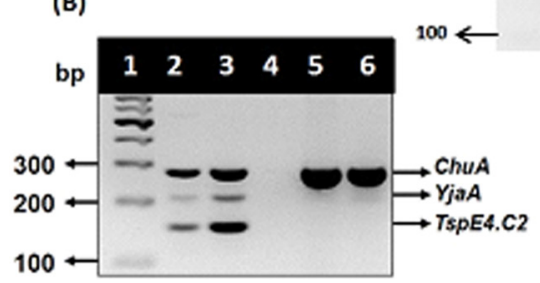

Fig.1. (A) Analysis of the PCR products in a 1.5\% agarose gel for the presence of virulence genes in the two 0157:H7 isolates. Lane 1: molecular mass marker (fragment size 900 to 100 bp), lane 2: positive control, lane 3: negative control, lane 4: 0157:H7 isolate 1 and lane 5: 0157:H7 isolate 2. Both isolates were positive for $16 \operatorname{SrRNA}$ (401 bp), stx2 (255 bp). (B) Analysis of PCR products in a 1.5\% agarose gel, showing the phylogenetic classification. Lane 1: molecular mass marker (fragment size 700 to $100 \mathrm{bp}$ ), lanes 2 and 3: positive control for group B2 containing the three genes: chuA (279 bp), yjaA (211 bp) and TspE4.C2 (152 bp), lane 4: negative control, lanes 5 and 6: the two 0157:H7 isolates positive for chuA only, characterizing them as group D. (C) Analysis of the PCR products in a $1.5 \%$ agarose gel for the presence of virulence genes in the two 0157:H7 isolates. Lane 1: molecular mass marker (fragment size 900 to $100 \mathrm{bp}$ ), lane 2: positive control, lane 3: 0157:H7 isolate 1, lane 4: 0157:H7 isolate 2. Both isolates were positive for fliCh7 (625 bp), rfb0157 (259 bp) and eae (248 bp).
The prevalence of $0157: \mathrm{H} 7$ in cows was $4.76 \%$ (1/21), $0 \%$ $(0 / 31)$ for calves and $1.92 \%(1 / 52)$ for all the animals studied. The farms prevalence was $4.76 \%(1 / 21)$.

\section{DISCUSSION}

EHEC 0157:H7 is not considered pathogenic for domestic animals and its occurrence in animals with enteric disease is considered incidental. However, it is a relatively common gut commensal, particularly in cattle, therefore livestock can act as a reservoir for human infection, with transmission either via either consumption of contaminated food (Reinstein et al. 2009) or through direct or indirect contact with animals or their feces (Rivero et al. 2011). Moreover, Bolton et al. (2011) showed that, although 0157:H7 strains do not occur frequently in pasture soils, they can persist in such an environment for several months, increasing the risk of infection for cattle. To date, no information has been published on the 0157:H7 status of dairy cattle in GO. This information is relevant due to the high milk production in the region.

In this study, one animal from 52 healthy dairy cattle was positive for the presence of 0157:H7 in a rectal swab. This is equivalent to a prevalence of $1.92 \%$. The reported prevalence of 0157:H7 in dairy cattle is highly variable. In the USA, Reinstein et al. (2009) reported a prevalence of 6.5\% (2/322). In Argentina, Tanaro et al. (2010) found that 11 out of the 288 (3.8\%) fecal samples were 0157 positive. In Brazil, Vicente et al. (2005) found a prevalence as high as $18.9 \%$ (86/454) for serogroup 0157 in some herds in São Paulo State. However, Sandrini et al. (2007) reported a prevalence of less than $0.3 \%(3 / 1127)$ in dairy cattle from Rio Grande do Sul State and Cerqueira et al. (1999) observed a prevalence of $1.5 \%$ (3/197) for 0157:H7 in healthy dairy cattle from Rio de Janeiro State. 
The presence of EHEC virulence markers in E. coli isolates represents a potential risk to human health and all 0157:H7 isolates possess a common combination of virulence factors: stx2, eae and rfb0157 (Pennington 2010). The two isolates identified in the current study included these virulent factors. Based on the epidemiological and experimental data, the frequency of the severe complications that can occur in bloody diarrhea is dependent on the toxin produced (Persson et al. 2007). The st 2 toxin may be a more significant factor for the development of HUS than stx1. Furthermore, the presence of st $x 2$ has been associated with a more virulent infection, partly due to its increased expression (Chattaway et al. 2011).

The enterohaemorrhagic haemolysin EhxA makes adherence possible for eaeA negative strains (Mainil \& Daube 2005). When both the ehxA and the eae genes are present this is an indicator for increased pathogenicity (Clermont et al. 2000). Both of the 0157:H7 isolates characterized in this study contained the ehxA and eae genes. EhxA is required for infection in humans and is common in ruminant STEC, providing further evidence of the link between bovine STEC and human disease (Bolton 2011). In Argentina, Padola et al. (2004) and Tanaro et al. (2010) showed that all 0157:H7 isolates were positive for the eae and ehxA genes.

The saa gene, responsible for producing autoagglutinating adhesin, has been involved in development of HUS (Paton et al. 2001). Several studies have showed that STEC isolated from cattle presenting saa are eae-negative (Paton et al. 2001, Toma et al. 2004, Cergole-Novella et al. 2006). Controversially, this study revealed the presence of both genes (saa and eae) in both 0157:H7 isolates, highlighting the pathogenic potential of them.

Pathogenicity markers in E. coli have been used in studies for phylogenetic classification to understand the evolution of microorganisms and they can be classified into four main groups: A, B1, B2 and D (Chao \& Dreyfus 1997). The virulent strains belong to groups B2 are characterized by the presence of chuA, yjaA and TSPE4.C2. The chuA gene is necessary for heme transport in EHEC, the function of the yjaA gene remains unknown and the TSPE4.C2 fragment is situated within a gene encoding a putative lipase esterase (Gordon et al. 2008). Strains classified into group D contain only the $c h u A$ gene. In this study, both of the 0157:H7 isolates were PCR positive for the presence of the chuA gene, indicating that they belonged to group $D$, suggesting that they had the potential to be highly pathogenic.

\section{CONCLUSIONS}

Both of the 0157:H7 isolates were considered highly pathogenic, as they were positive for the presence of the stx2, eae, ehxA, saa, cnf1 and chuA virulence factor genes, thereby representing a potential risk for humans.

The results of the current study suggest that healthy dairy cattle from Mid-West of Brazil may be an important reservoir of highly pathogenic 0157:H7 and that their far$\mathrm{ms}$ are potential sources of environmental contamination through shedding of microorganisms in cattle feces.
Acknowledgements.- The authors are indebted to the owners and farm workers for their generous assistance and cooperation in collection of the samples. This study was supported by grant $503886 / 2009-2$ from Conselho Nacional de Desenvolvimento Científico e Tecnológico (CNPq).

\section{REFERENCES}

Blanco M., Blanco J.E., Alonso M.P., Balsalobre C., Mouriño M., Madrid C. \& Juárez A. 1996. Polymerase chain reaction for detection of Escherichia coli strains producing cytotoxic necrotizing fator type 1 and type 2 (CNF1 and CNF2). J. Microbiol. Meth. 26:95-101.

Blanco M., Blanco J.E., Mora A., Dahbi G., Alonso M.P., González E.A., Bernádez M.I. \& Blanco J. 2004. Serotypes, virulence genes, and intimin types of shiga toxin (verotoxin)-producing Escherichia coli isolates from cattle

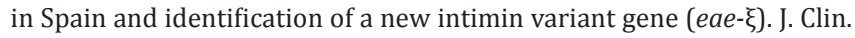
Microbiol. 42:645-651.

Bolton D.J., Monagha A., Byrne B., Fanning S., Sweeney T. \& McDowell D.A. 2011. Incidence and survival of non-0157 verocytotoxigenic Escherichia coli in soil. J. Appl. Microbiol. 111:484-490.

Bolton D.J. 2011. Verotocytotoxigenic (Shiga toxin-producing) Escherichia coli: virulence factors and pathogenecity in the farm to fork paradigm. Foodborne Pathog. Dis. 8:1-10.

Cergole-Novella M.C., Nishimura L.S., Irino K., Vaz T.M., De Castro A.F.P., Leomil L. \& Guth B.E.C. 2006. Stx genotypes and antimicrobial resistance profile of Shiga toxin-producing Escherichia coli strains isolated from human infections, cattle and foods in Brazil. FEMS Microbiol. Lett. 259:234-239.

Cerqueira A.M.F., Guth B.E.C., Joaquim R.M. \& Andrade J.R.C. 1999. High occurrence of shiga toxin-producing Escherichia coli (STEC) in healthy cattle in Rio de Janeiro State, Brazil. Vet. Microbiol. 70:111-121.

Chao K.L. \& Dreyfus L.A. 1997. Interaction of Escherichia coli heat-stable enterotoxin B with cultured human intestinal epithelial cells. Infect. Immun. 65:3209-3217.

Chattaway M.A., Dallman T., Okeke I.N. \& Wain J. 2011. Enteroaggregative E. coli 0104 from an outbreak of HUS in Germany 2011, could it happen again? J. Infect. Dev. Ctries 5:425-436.

Clermont O., Bonacorsi S. \& Bingen E. 2000. Rapid and simple determination of the Escherichia coli phylogenetic group. Appl. Environ. Microbiol. 66:4555-4558.

Cookson A.L., Bennett J., Thomson-Carter F. \& Attwood G.T. 2007. Molecular subtyping and genetic analysis of the Enterohemolysin gene (ehxA) from Shiga toxin-producing Escherichia coli and atypical Enteropathogenic E. coli. Appl. Environ. Microbiol. 73:6360-6369.

Feng P., Weagant S.D. \& Grant M.A. 2009. Enumeration of Escherichia coli and the coliform bacteria. [Database on the Internet] In: Bacteriological Analytical Manual online. Food and Drug Administration (FDA). c 2002 [updated 2009 Apr. 11]. Available from <http://www.cfsan.fda.gov/>

Gannon V.P.J., D’Souza S., Graham T., King R.K., Rahn K. \& Read S. 1997. Use of the flagellar $\mathrm{H7}$ gene as a target in multiplex PCR assays and improved specificity in identification of Enterohemorrhagic Escherichia coli strains. J. Clin. Microbiol. 35:656-662.

Gordon D.M., Clermont O., Tolley H. \& Denamur E. 2008. Assigning Escherichia coli strains to phylogenetic groups: multi-locus sequence typing versus the PCR triplex method. Environ. Microbiol. 10:2484-2496.

Hussein H.S. 2007. Prevalence and pathogenicity of Shiga toxin-producing Escherichia coli in beef cattle and their products. J. Anim. Sci. 85:63-72.

IBGE 2012. Instituto Brasileiro de Geografia e Estatística. [Database on the Internet] In: Pesquisa Pecuária Municipal 1974-2010. c 2012 [updated 2012 Jan. 1]. Available from <http://www.sidra.ibge.gov.br/bda/pesquisas/ppm/default.aspsed $>$

Johnson T.J. \& Nolan L.K. 2009. Pathogenomics of the virulence plasmids of Escherichia coli. Microbiol. Mol. Biol. Rev. 73:750-774.

Karmali M.A., Gannon V. \& Sargeant J.M. 2010. Verocytotoxin-producing Escherichia coli (VTEC). Vet. Microbiol. 140:360-370.

Keskimaki M., Attila L., Peltola H. \& Siitonen A. 2001. EPEC, EHAC and STEC in stool specimens: prevalence and molecular epidemiology of isolates. Diagn. Microbiol. Infect. Dis. 40:151-156. 
Mainil J.G. \& Daube G. 2005. Verotoxigenic Escherichia coli from animals, humans and foods: who's who? J. Appl. Microbiol. 98:1332-1344.

Padola N.L., Sanz M.E., Blanco J.E., Blanco M., Blanco J., Etcheverria A.I., Arroyo G.H., Usera M.A. \& Parma A.E. 2004. Serotypes and virulence genes of bovine Shigatoxigenic Escherichia coli (STEC) isolated from a feedlot in Argentina. Vet. Microbiol. 100:3-9.

Paton A.W. \& Paton J.C. 1998. Detection and characterization of Shiga toxigenic Escherichia coli by using multiplex PCR assays for stx1, stx2, eaeA, Enterohemorrhagic E. coli hlyA, rfb0111, and rfb0157. J. Clin. Microbiol. 36:598-602.

Paton A.W. \& Paton J.C. 2002. Direct detection and characterization of Shiga toxigenic Escherichia coli by multiplex PCR for $s t x_{1}, s t x_{2}, e a e, e h x A$, and saa. J. Clin. Microbiol. 40:271-274.

Paton A.W., Srimanote P., Woodrow M.C. \& Paton J.C. 2001. Characterization of $S a a$, a novel auto agglutinating adhesin produced by locus of enterocyte effacement-negative Shiga-toxigenic Escherichia coli strains that are virulent for humans. Infect. Immun. 69:6999-7009.

Pennington H. 2010. Escherichia coli 0157. Lancet 376:1428-1435.

Persson S., Olsen K.E.P., Ethelberg S. \& Scheutz F. 2007. Subtyping method for Escherichia coli Shiga toxin (Verocytotoxin) 2 variants and correlations to clinical manifestations. J. Clin. Microbiol. 45:2020-2024.

Reinstein S., Fox J.T., Shi X., Alam M.J., Renter D.G. \& Nagaraja T.G. 2009. Prevalence of Escherichia coli 0157:H7 in organically and naturally raised beef cattle. Appl. Environ. Microbiol. 75:5421-5423.

Rivero M.A., Passucci J.A., Rodriguez E.M., Signorini M.L., Tarabla H.D. \& Parma A.E. 2011. Factors associated with sporadic verotoxigenic Escherichia coli infection in children with diarrhea from the Central Eastern Area of Argentina. Foodborne Pathog. Dis. 8:901-906.
Rúgeles L.C., Bai J., Martínez A.J., Vanegas M.C. \& Gómez-Duarte O.G. 2010. Molecular characterization of diarrheagenic Escherichia coli strains from stools samples and food products in Colombia. Int. J. Food Microbiol. 138:282-286.

Sandrini C.N.M., Pereira M.A., Brod C.S., Carvalhal J.B. \& Aleixo J.A.G. 2007. Escherichia coli verotoxigênica: isolamento e prevalência em 60 propriedades de bovinos de leite da região de Pelotas, RS, Brasil. Ciência Rural 37:175-182.

Sousa L.O., Campos S.A.C. \& Gomes M.F.M. 2012. Technical performance of milk producers in the State of Goiás, Brazil, in the short and long terms. R. Bras. Zootec. 41:1944-1950.

Tanaro J.D., Leotta G.A., Lound L.H., Galli L., Piaggio M.C., Carbonari C.C., Araujo S. \& Rivas M. 2010. Escherichia coli 0157 in bovine feces and surface water streams in a beef cattle farm of Argentina. Foodborne Pathog. Dis. 7:475-479.

Toma C., Espinosa E.M., Canção T., Miliwebsky E., Chinen I., Iyoda S., Iwanaga M. \& Rivas M. 2004. Distribution of putative adhesins in different seropathotypes of shiga toxin-producing Escherichia coli. J. Clin. Microbiol. 42:4937-4946.

Vicente H.I.G., Amaral L.A. \& Cerqueira A.M.F. 2005. Shigatoxigenic Escherichia coli serogroups 0157, 0111 and 0113 in feces, water and milk samples from dairy farms. Braz. J. Microbiol. 36:217-222.

Wang G., Clark C.G. \& Rodgers F.G. 2002. Detection in Escherichia coli of the genes encoding the major virulence factors, the genes defining the 0157:H7 serotype, and components if the type 2 Shiga toxin family by multiplex PCR. J. Clin. Microbiol. 40:3613-3619.

Yamamoto S., Terai A., Yuri K., Kurazono H., Takeda Y. \& Yoshida O. 1995. Dectection of urovirulence factors in Escherichia coli by multiplex polymerase chain reaction. Med. Microbiol. Immunol. 12:85-90. 